\title{
Establishing a protocol for single cell transcriptome sequencing of the rat brain
}

\author{
Hao Chen, Burt M Sharp* \\ From UT-KBRIN Bioinformatics Summit 2014 \\ Cadiz, KY, USA. 11-13 April 2014
}

\section{Background}

The rat is a widely used model for neuroscience research, particularly for complex behavioral phenotypes. We tested the feasibility of RNA-seq analysis of single cells located in the dopaminergic midbrain region, which is critical for motivated behaviors.

\section{Materials and methods}

Brain tissue of interest from adult Sprague-Dawley rats was obtained in bilateral punches from fresh $1 \mathrm{~mm}$ thick coronal sections, using a 3D-printed device for guidance. The method of Guez-Barber et al. [1] was then followed to dissociate cells. Using flow cytometry, we determined that cell viability was $93-95 \%$ and neurons (i.e., $\mathrm{NeuN}+$ ) were approximately $50 \%$. Cell suspensions were separated in the C1 single-cell auto prep instrument into individual cells. cDNA synthesis and amplification were then performed for each cell in the integrated microfluidic circuits. Fourteen cells were selected for whole transcriptome sequencing using the Ion Proton instrument based on their morphology, positive PCR detection of marker genes, and quantity of cDNA. The Ion Torrent Suite was used to map the reads ( $150 \mathrm{bp}$ in length) to the rat reference genome (rn5).

\section{Results}

On average, 3,928 \pm 434 genes were detected per cell (excluding one cell that failed at the library prep step and one at the sequencing step), and a significantly greater number of genes (i.e., 5,226 \pm 54 ) were detected from three cells with higher cDNA content compared to the other nine cells. Only one cell expressed the stress-marker, cFos. Three cell types can be identified: neurons (expressing Th, Slc6a3, Slc17a7, Gad2, etc, $\mathrm{n}=3$ ), astrocytes (expressing

\footnotetext{
* Correspondence: bsharp@uthsc.edu

Department of Pharmacology, University of Tennessee Health Science Center, Memphis, TN 38106, USA
}

(c) 2014 Chen and Sharp; licensee BioMed Central Ltd. This is an Open Access article distributed under the terms of the Creative Commons Attribution License (http://creativecommons.org/licenses/by/4.0), which permits unrestricted use, distribution, and reproduction in any medium, provided the original work is properly cited. The Creative Commons Public Domain Dedication waiver (http://creativecommons.org/publicdomain/zero/1.0/) applies to the data made available in this article, unless otherwise stated. 